Review article

\title{
Work environment assessment instruments used in nursing
}

\author{
Eva Janíková ${ }^{1,2}$ *, Renáta Zeleníková ${ }^{1}$, Darja Jarošová ${ }^{1}$, Ilona Plevová ${ }^{1}$, Eva Mynaříková ${ }^{2}$ \\ ${ }^{1}$ University of Ostrava, Faculty of Medicine, Department of Nursing and Midwifery, Ostrava, Czech Republic \\ ${ }^{2}$ University Hospital Ostrava, Czech Republic
}

\begin{abstract}
The aim was to identify and characterize instruments for assessing the work environment of nurses.

The sources of information were articles in six electronic databases. Prior to the search, a clinical question was constructed: "Which instruments are suitable for assessing the work environment of hospital nurses?" The query words were practice/work environment, nursing, scale. The search, using Boolean operators and limited to the period of 2010-2020, was performed from May to June 2020. The inclusion criteria were: empirical study, description of methods used, and an available English full text.

From a total of 1,212 identified articles, 57 were selected for the final analysis. The studies used as many as 23 instruments. The most common ones were the Practice Environment Scale - Nursing Work Index (PES-NWI) or the variants Practice Environment Scale and Nursing Work Index, followed by Brisbane Practice Environment Measure and Revised Professional Practice Environment. The work environment was assessed along with other variables such as burnout syndrome or workload.

Among the numerous instruments for monitoring the work environment, the PES-NWI was most commonly used. The instrument has also been translated into the Czech language. The study results suggest that the quality of the work environment is associated, for example, with nurses' job satisfaction or burnout syndrome, illustrating the importance of this issue in the Czech setting.
\end{abstract}

Keywords: Assessment; Instrument; Nurse; Nursing; Work environment

\section{Introduction}

The work environment may be characterized as a set of factors influencing individuals which, conversely, are co-shaped by these individuals' activity. The work environment and its conditions are regulated by Czech legislation, namely Government Decree No. 246/2018 Coll., National Occupational Health and Safety Policy of the Czech Republic and related acts such as Act No. 258/2000 Coll., On protection of public health. The ideal work environment is one that provides conditions for physical, mental and social (or spiritual) well-being. The International Standard ISO 6385:2016 (2016) defines work environment as the physical, chemical, biological, organizational, social and cultural factors which surround a worker. The American Association of Critical-Care Nurses identified six standards for healthy work environments. These include skilled-communication, true collaboration, effective decision-making, appropriate staffing, meaningful recognition and authentic leadership (AACN, 2016). Given the nature of nurses' work, the work environment is an important factor in their motivation to better perform their jobs. In the USA, the term Magnet Hospitals refers to institutions with high levels of independence and control over the work, good nurse-physician relationships, lower employee turnover rates, opportunities to take part in further education, nurse engagement in hospital affairs, and promotion of quality patient care. These hospitals are typically able to acquire and maintain adequate staff (Walket et al., 2010). Thus a Magnet Hospital may be understood as a nurse-friendly institution.

The quality of the work environment is an important factor influencing the quality of nursing care provided - and thus requires a more detailed analysis (Cho and Han, 2018). Work environment quality is related to job satisfaction, nurse turnover, burnout syndrome and care quality (Van Bogaert et al., 2013a; Warshawsky and Havens, 2011). According to Christiansen et al. (2015), it is linked to motivation for better performance. Smith et al. (2018) point to an association between nurse incivility and unsupportive management/leadership or staffing inadequacy. Other studies showed links between the work environment and individual aspects of care provided such as lower patient mortality (Cho et al., 2015), fewer falls (Purdy et al., 2010), fewer nosocomial infections, and fewer medication errors (Van Bogaert et al., 2014). The work environment also influences the staff's attitude towards their own health and perception of the workload (Fagerström and Vainikainen, 2014; Tucker et al., 2010).

Work environment assessments are important indicators for hospital management and may be used in workforce planning and to predict needs regarding the nursing profession

\footnotetext{
* Corresponding author: Eva Janíková, University of Ostrava, Faculty of Medicine, Department of Nursing and Midwifery, Syllabova 19, 70003 Ostrava-Vítkovice, Czech Republic; e-mail: eva.janikova@osu.cz http://doi.org/10.32725/kont.2021.041 
(Efstathiou et al., 2018). Worldwide, a multitude of instruments are used to assess the work environment. Their authors usually focus on individual factors that have been confirmed to play an important role in shaping the work environment (Perry et al., 2018). The two most common instruments are PES-NWI and NWI-R; their use has gradually increased (Norman and Sjetne, 2017; Warshawsky and Havens, 2011). Each consists of several domains covering particular areas of the work environment.

The aim was to identify and characterize instruments for assessing the work environment of nurses.

\section{Materials and methods}

\section{Search strategy and selection criteria}

The sources of information were articles that met the selection criteria in six electronic databases (Academic Search Complete, Academic Search Ultimate, Medline Complete, CINAHL Plus with Full Text, Science Direct, OpenAIRE). Prior to the search, a PICO clinical question was constructed: "Which instruments (I) are suitable for assessing the work environment (O) of hospital nurses (P)?" The query words were practice/work environment, nursing, scale. The selected keywords were entered in a search engine using the Boolean operators AND/OR. The search was limited to the period of 2010-2020, English language and full texts of articles. The search was performed from May to June 2020. The inclusion criteria were: empirical study, use of a work environment assessment instrument, description of methods used and an available English full text.

\section{Article selection}

From a total of 1,212 articles, 737 were excluded as duplicates. A total of 379 out of the remaining 475 articles were excluded for not meeting the search criteria (full text not available, language other than English, inconsistency with the PICO question). 96 articles were assessed for relevance based on abstract and full text. Finally, 57 articles were selected for the analysis (Fig. 1).

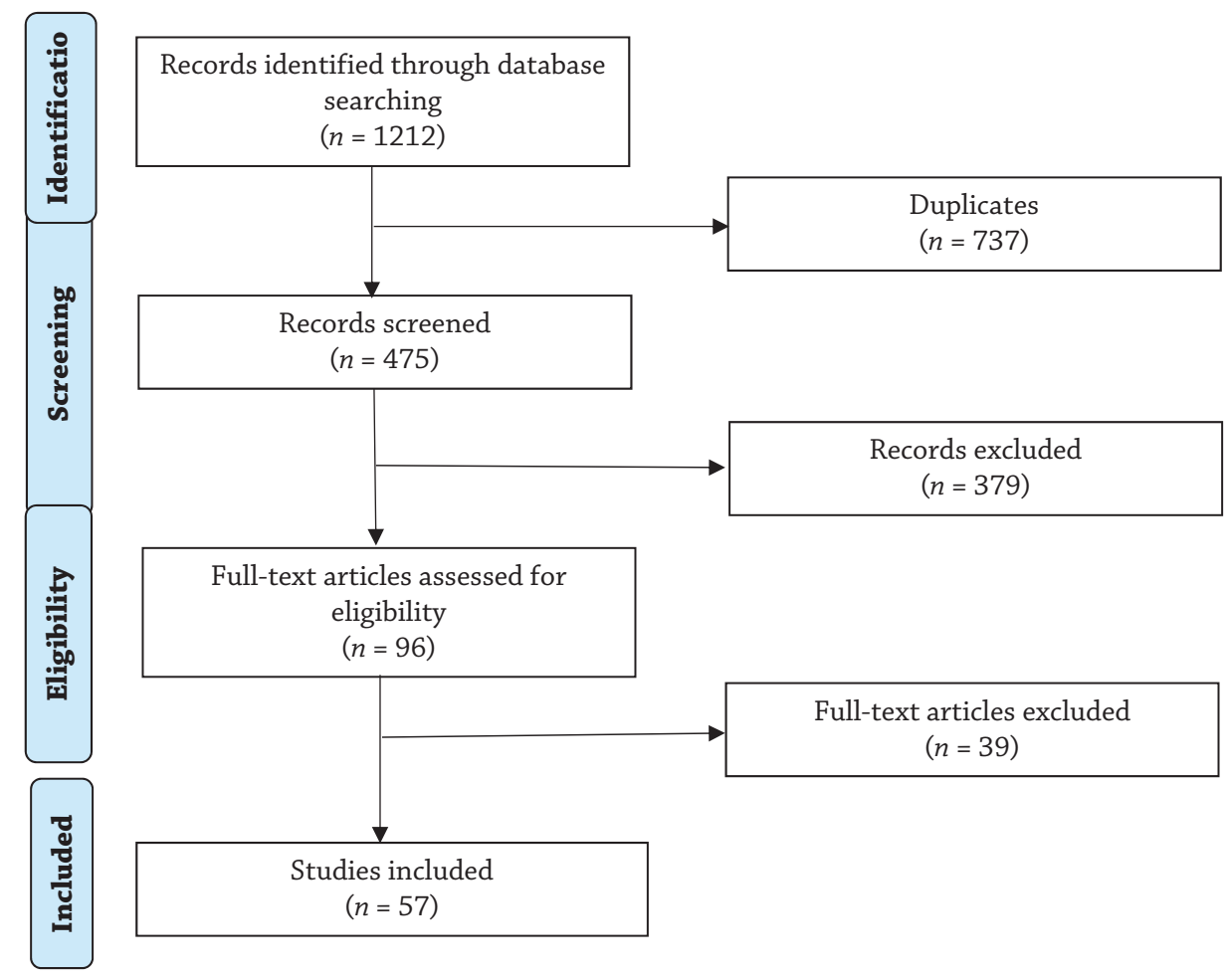

Fig. 1. PRISMA flow diagram (Klugar, 2015; Moher et al., 2009)

\section{Results}

The identified studies suggest that the work environment is viewed from various perspectives and it has long been considered an important issue worldwide. These studies used as many as 23 instruments. The most common ones were the Practice Environment Scale - Nursing Work Index (20 studies) or the variants Practice Environment Scale (6 studies) and Nursing Work Index (9 studies). Other instruments were the Brisbane Practice Environment Measure (3 studies) and the Revised Professional Practice Environment (2 studies). In the other cases, each instrument was used in only one study. With all instruments, higher scores mean a more positive work environment.

The work environment was assessed along with job satisfaction in 12 studies (e.g. Gasparino and Guirardello, 2017; Wang et al., 2015), with burnout syndrome in six studies (e.g. Gasparino and Guirardello, 2017; Hayes et al., 2015; Panunto and Guirardello, 2013; Van Bogaert et al., 2013b), or stress in two studies (Bratt and Felzer, 2011; Hayes et al., 2015). Other variables assessed together with the work environment were workload in two studies (Van Bogaert et al., 2013b, c), or intention to leave the current workplace in six studies 
(e.g. Cortelyou-Ward et al., 2010; Nantsupawat et al., 2017). Additionally, the work environment was studied with respect to the quality of care provided in three studies (e.g. Gea-Cabalero et al., 2019), missed nursing care in two studies (Park et al., 2018; Silva et al., 2020), or the impact it has on patients in one study. In the Person-Centered Nursing Index, job satisfaction (18 items) and job stress (36 items) are integral components, besides the work environment (Kurjenluoma et al., 2017). If stated, the instrument's reliability was measured for both total scores and separate subscales. Cronbach's alpha was above 0.7 for total scores and most subscales. The only exceptions were the SC-IQ, RPPE, R-IWPS, QNWL, PES-NWI, NWI and Chinese PES, with some studies showing Cronbach's alpha below 0.7 for some of their subscales. The greatest proportion of studies (35) were conducted in clinical departments of both public and private hospitals (e.g. Tang and Idris, 2016) of various sizes (e.g. Pires et al., 2018). Some studies focused on particular types of departments such as emergency departments (e.g. Schadewaldt et al., 2019) or intensive care units. Four studies were concerned with primary care (e.g. Gea-Cabalero et al., 2019), three studied the work environment in military hospitals (e.g. Swiger et al., 2017), and two in nursing homes (e.g. Wang et al., 2015). The numbers of items vary considerably between different instruments. The fewest items (less than 10) are in the REAL, PPEAS and Evidence-Based Work Environment Scale. By contrast, the greatest numbers of items (more than 50) are contained in the ACT, EOMII and Modified 6-D Scale of Nursing Performance. If specified, respondents rate their answers on a Likert scale (4 to 10 points); only one study uses a faces scale. In any case, those are self-report instruments (Suppl. Table 1).

The literature search has shown that, as a basic instrument, the NWI inspired the development of many others. The NWI was created by Kramer and Hafner in 1989, following research carried out in well-staffed hospitals (so-called Magnet Hospitals) in the 1980s. It originally consisted of 65 items (4 domains) that lacked empirical verification and were rather numerous for users (Lake, 2002). The authors also used the instrument in the military setting, with items being divided into five domains without additional explanation (Estabrooks et al., 2002). Later, the 65 items were adapted to 57 items (55 original and two new ones) in three domains. Out of those, 15 items were selected to create the Nursing Work Index-Revised (NWI-R) with the following three domains: Autonomy (5 items), Control over the Work Environment/Practice Settings (7 items), and Relationships with Physicians (3 items). Another domain (Organizational Support) comprised 10 items from the previous domains. The remaining items are concerned with department and hospital outcomes (Aiken and Patrician, 2000; Lake, 2007). In a study by Slater and McCormack (2007), the NWI was subjected to factor analysis; as a result, the original 15 NWI items were divided into three domains (Adequate Staff and Support, Doctor-Nurse Relationship, Nursing Management) instead of four. Estabrooks et al. (2002) developed the Practice Environment Index (PEI) based on the NWI, containing 49 NWI items and two items reflecting the Canadian setting (Oshodi et al., 2017). Its abridged version containing 26 items is recommended by the author for monitoring nurses' work environment (Estabrooks et al., 2002). Following revision of the NWI, Lake (2002) created the Practice Environment Scale (PES) by selecting 48 out of the original 65 items to be tested. Eventually, 31 items were selected and divided into five domains. The instrument is referred to as the Practice Environment Scale or, alternatively, as the Practice Environment Scale-Nursing Work Index. Choi et al. (2004) studied 57 NWI items to select 42 which were divided into seven subscales/domains (Professional Practice, Nursing Management, Staffing and Resources Adequacy, Nursing Process, Nurses-Physician Collaboration, Nursing Competence, Positive Scheduling Climate). The instrument is called Perceived Nursing Work Environment (PNWE). Slater et al. (2010) revised the NWI and identified 33 items in six domains (Career Opportunities/Advancement, Nursing Process, Nurse Participation, Adequate Staff and Resources, Collaborative Working with Doctors, Nurse Management), renaming two original domains (Control over Practice to Adequate Staff and Resources, Autonomy to Nurse Management). Other instruments derived from the NWI are, for example, the EOMII (Oshodi et al., 2017), C-NPES (Chiang and Lin, 2009), and C-PNWE (Choi et al., 2004).

The most commonly used instrument is the PES-NWI developed by Eileen T. Lake based on the NWI. Its 31 items are classified into five subscales (Nurse Participation in Hospital Affairs, Nursing Foundations for Quality of Care, Nurse Manager Ability, Leadership and Support of Nurses, Staffing and Resource Adequacy, Collegial Nurse-Physician Relations). Each of them contains 3-10 items. The domains Nurse Participation in Hospital Affairs and Nursing Foundations for Quality of Care are indicators of the work environment in the hospital as a whole, while the other three domains reflect the work environment in particular departments (Lake, 2002). After the mean score is calculated for each domain, the work environment is classified as favorable (a mean score above 2.5 in at least four subscales), mixed (a mean score above 2.5 in two or three subscales) or poor (a mean score above 2.5 in one or no subscale) (Lake and Friese, 2006). Shorter versions of the instrument are targeted at specific settings, for example a 10-item Spanish version for primary care (De Pedro-Goméz et al., 2012) or a version for the ambulatory oncology setting containing six domains with 25 items (Friese, 2012). As can be seen from the identified studies (Suppl. Table 1), the instrument has been translated into many languages and is used in numerous countries including Australia, USA, South Africa, China, South Korea, Thailand, Turkey, Iran, Greece or Spain. It has been used in various areas of healthcare, from primary and community care, to military hospitals or nursing homes, to oncology outpatient care. To a certain extent, the results may be generalized but specific characteristics of different settings need to be taken into account.

\section{Discussion}

The vast number of original articles underline the fact that the work environment of nurses is a topical and global issue. That is why so many assessment instruments have been created. The basic instrument appears to be the NWI which has inspired the development of many others, depending on their authors' specific perspectives. Swiger et al. (2017) recommend the use of the PES-NWI, mainly for its good psychometric properties, high discriminatory power and ability to compare results between studies (as well as within various countries). It is the number of studies using a particular instrument that may be one of the factors influencing instrument selection. Additionally, the PES-NWI was identified as sensitive for monitoring nurses' work environment by the National Quality Forum (NQF, 2004). On the other hand, some of the criticisms are that its items were formulated in the 1980s and for inpatient facilities (Friese, 2012). The wording has been updated and the instrument has been adapted for use in other settings (e.g. 
primary or outpatient oncology care) by other authors who continue working with the instrument (e.g. De Pedro Goméz et al., 2012; Friese, 2012; Rabie et al., 2016). According to the recommendations for questionnaire development (Olecká and Ivanová, 2010), filling out the questionnaire should not take longer than about 20 minutes, which corresponds to about 40-50 questionnaire items. In this respect, the PES-NWI tool is satisfactory.

Instrument subscales correspond to basic factors influencing the work environment generally (not only that of nurses). Their formulation may be based on, for example, psychological theories of human motivation and behavior. These may be self-determination theory (Perry et al., 2018) or Maslow's motivational theory (Kolman et al., 2009).

In the context of Czech nursing, the interest in nurses' work environment is reflected in many recent projects and research activities (e.g. Mikšová et al., 2020; Novotná, 2018; Polanská et al., 2020; Žezulková, 2018). For the latter two studies, the PES-NWI was translated into Czech. Žežulková (2018) reported the internal consistency (Cronbach's alpha) of the Czech version to be $0.45-0.74$ for individual subscales and 0.86 for the total score. The reported reliability appears to be lower compared to studies from other countries (e.g. Efstathiou et al., 2018). In 2017, the instrument was also translated by Jarošová and Zeleníková (2017). The two Czech versions are similar to each other; there are minor differences in word order or item wording but the meaning of items is identical.

\section{Conclusions}

The work environment is an issue that has been dealt with in many articles. Of the 23 identified instruments for work environment assessment, the PES-NWI is most frequently used. This instrument has already been translated into the Czech language and appears to be suitable for assessing the Czech work environment.The study results suggest that the quality of the work environment is associated with nurses' job satisfaction, burnout syndrome, etc.

Given the consequences of the work environment, the translation and validation of selected work environment assessment instruments for their use in the Czech setting are important steps. Thus the availability and accessibility of Czech translations may be one of the factors influencing the wide-scale use of instruments for work environment monitoring - as well as their dissemination among healthcare professionals. Further research (e.g. interventional studies) could focus on various measures that may have a positive impact on the work environment quality.

\section{Ethical aspects and conflict of interests}

The authors have no conflict of interests to declare.

\section{Acknowledgements}

Supported by the Ministry of Health of the Czech Republic project no. NV18-09-00420. All rights reserved.

\title{
Měřici nástroje použivané pro hodnocení pracovního prostředí v ošetřovatelství
}

\begin{abstract}
Souhrn
Cílem práce bylo vyhledat nástroje zaměřené na hodnocení pracovního prostředí sester a popsat jejich charakteristiku.

Zdrojem informací byly články z 6 elektronických databází. Před zahájením vyhledávání byla stanovena klinická otázka: „Které nástroje jsou vhodné pro hodnocení pracovního prostředí sester v nemocnici?“. Klíčová slova byla: practice/work environment, nursing, scale. Vyhledávání probíhalo pomocí booleovských operátorů od května do června 2020, pro období let 2010-2020. Zařazovacími kritérii byly: empirická studie s uvedením metodologie a dostupný full text v anglickém jazyce.

Celkem bylo nalezeno 1212 studií, pro konečné zpracování jich bylo použito 57 . Ve vyhledaných studiích bylo použito celkem 23 nástrojů. Mezi nejčastěji použité nástroje patří Practice Environment Scale-Nursing Work Index a jeho varianty Practice Environment Scale, Nursing Work Index, dále pak Brisbane Practice Environment Measure a Revised Professional Practice Environment. Spolu s pracovním prostředím byly zkoumány další proměnné, např. syndrom vyhoření, pracovní zátěž apod.

Z množství nalezených nástrojů, které se používají pro monitoring pracovního prostředí, byl nejčastěji použit dotazník PES-NWI. Tento dotazník je již přeložen také do českého jazyka. Z výsledků publikací pak vyplývá souvislost kvality pracovního prostředí a např. pracovní spokojenosti, syndromu vyhoření apod., což je dokladem důležitosti tématu i v českém prostředí.
\end{abstract}

Klíčová slova: dotazník; nástroj; ošetřovatelství; pracovní spokojenost; sestra

\section{References}

1. AACN (2016). Standards for Establishing and Sustaining Healthy Work Environments: A Journey to Excellence, 2nd ed. [online] [cit. 2021-05-05]. Available from: www.aacn.org/ nursing-excellence/aacn-standards

2. Act No. 258/2000 Coll., On protection of public health [Zákon č. 258/2000 Sb., o ochraně veřejného zdraví a o změně některých souvisejících zákonů]. In: Sbírka zákonů České republiky, částka $74 / 2000$.

3. Aiken LH, Patrician PA (2000). Measuring Organizational Traits of Hospitals: The Revised Nursing Work Index. Nurs Res 49(3): 146-153. DOI: 10.1097/00006199-200005000-00006.
4. Al Sabei SD, Labraque LJ, Miner Ross A, Karada S, Albashayreh A, Al Masroori F, Al Hashmi N (2020). Nursing Work Environment, Turnover Intention, Job Burnout, and Quality of Care: The Moderating Role of Job Satisfaction. J Nurs Scholarsh 52(1): 95-104. DOI: 10.1111/jnu.12528.

5. Asiret GD, Kapucu S, Kose TK, Kurt B, Ersoy NA (2017). Attitudes and Satisfaction of Nurses with the Work Environment in Turkey. Int J Car Science 10(2): 771-780.

6. Balsanelli AP, Cunha ICKO (2013). The work environment in public and private intensive care units. Acta Paul Enferm 26(6): 561-568. DOI: redalyc.org/articulo.oa?id=307029916009.

7. Bratt MM, Felzer HM (2011). Perceptions of Professional Practice and Work Environment of New Graduates in a Nurse Residency Program. J Contin Educ Nurs 42(12): 559-568. DOI: 10.3928/00220124-20110516-03. 
8. Cao Y, DiGiacomo M, Salamonson Y, Li Y, Huai B, Davidson PM (2015). Nurses' perceptions of their professional practice environment: a cross-sectional study. J Clin Nurs 24(23-24): 3441-3448. DOI: 10.1111/jocn.12953.

9. Cheng L, Cui Y, Chen Q, Ye Y, Liu Y, Zhang F, et al. (2020). Paediatric nurses' general self-efficacy, perceived organizational support and perceived professional benefits from Class A tertiary hospitals in Jilin province of China: the mediating effect of nursing practice environment. BMC Health Serv Res 20(1): 12. DOI: 10.1186/s12913-019-4878-3.

10. Chiang H-Y, Lin S-Y (2009). Psychometric testing of the Chines version of nursing practice environment scale. J Clin Nurs 18(6): 919-929. DOI: 10.1111/j.1365-2702.2008.02433.x.

11. Cho E, Sloane DM, Kim E-Y, Kim S, Choi M, Yoo IY, et al. (2015). Effects of nurse staffing, work environments, and education on patient mortality: An observational study. Int J Nurs Stud 52(2): 535-542. DOI: 10.1016/j.ijnurstu.2014.08.006.

12. Cho H, Han K (2018). Associations among Nursing Work Environment and Health-Promoting Behaviors of Nurses and Nursing Performance Quality: A Multilevel Modeling Approach. J Nurs Scholarsh 50(4): 403-410. DOI: 10.1111/jnu.12390.

13. Choi J, Bakken S, Larson E, Du Y, Stone PW (2004). Perceived Nursing Work Environment of Critical Care Nurses. Nurs Res 53(6): 370-378. DOI: 10.1097/00006199-200411000-00005.

14. Christiansen C, Baum CM, Bass JD (2015). Health, occupational performance, and occupational therapy. In: Christiansen C, Baum CM, Bass JD (Eds). Occupational therapy: Performance, participation and well-being. Thorofare, NJ: SLACK, pp. 7-22.

15. Cortelyou-Ward KH, Unruh L, Fottler MD (2010). The effect of work environment on intent to leave the nursing profession: a case study of bedside registered nurses in rural Florida. Health Serv Manage Res 23(4): 185-192. DOI: 10.1258/ hsmr.2010.010008.

16. Costa NN, de Camargo Silva AEB, de Lima JC, Bezerra ALQ Sagawa MR, de Sousa MRG (2018). Pediatric work environment: satisfaction of nursing professionals. J Nurs UFPE online Recife 12(12): 3327-3336. DOI: 10.5205/1981-8963-v12i12a234975p3327-3336-2018.

17. De Pedro-Gómez J, Morales-Asencio JM, Sesé-Abad A, Bennasar-Veny M, Pericas-Beltran J, Miguélez-Chamorro A (2012). Psychometric testing of the Spanish version of the Practice Environment Scale of the Nursing Work Index in a primary healthcare context. J Adv Nurs 68(1): 212-221. DOI 10.1111/j.1365-2648.2011.05730.x.

18. Efstathiou G, Andreou C, Tsangari H, Dimitriadou M, Papastavrou E (2018). Adaptation and validation of the Cyprus version of the Practice Environment Scale of the Nursing Work Index: a methodological study. BMC Res Notes 11(1): 791. DOI: 10.1186/s13104-018-3896-2.

19. Elmi S, Hassankhani H, Abdollahzadeh F, Abadi MAJ, Scott J, Nahamin M (2017). Validity and Reliability of the Persian Practice Environment Scale of Nursing Work Index. Iran J Nurs Midwifery Res 22(2): 106-111. DOI: 10.4103/17359066.205953.

20. Estabrooks CA, Tourangeau AE, Humphrey CK, Hesketh KL, Giovannetti P, Thomson D, et al. (2002). Measuring the Hospital Practice Environment: A Canadian Context. Res Nurs Health 25(4): 256-268. DOI: 10.1002/nur.10043.

21. Fagerström L, Vainikainen P (2014). Nurses' experiences of nonpatient factors that affect nursing workload: A study of the PAONCIL instrument's nonpatient factors. Nurs Res Pract 2014: 167674. DOI: 10.1155/2014/167674.

22. Flint A, Farrugia C, Courtney M, Webster J (2010). Psychometric Analysis of the Brisbane Practice environment Measure (B-PEM). J Nurs Scholarsh 42(1): 76-82. DOI: 10.1111/j.1547-5069.2009.01328.x.

23. Flynn L, Liang Y, Dickson GL, Xie M, Suh D-C (2012). Nurses' practice environments, Errors Interception Practices, and Inpatient Medication Errors. J Nurs Scholarsh 44(2): 180-186. DOI: 10.1111/j.1547-5069.2012.01443.x.

24. Friese CR (2012). Practice Environments of Nurses Employed in Ambulatory Oncology Settings: Measure Refinement. Oncol Nurs Forum 39(2): 166-172. DOI: 10.1188/12.ONF.166-172.
25. Ganz FD, Toren O (2014). Israeli nurse practice environment characteristics, retention, and job satisfaction. Isr J Health Policy Res 3(1): 7. DOI: 10.1186/2045-4015-3-7.

26. Gasparino RC, Guirardello EB (2017). Validation of the Practice Environment Scale to the Brazilian culture. J Nurs Manag 25(5): 375-383. DOI: 10.1111/jonm.12475.

27. Gea-Cabalero V, Castro-Sánchez E, Júarez-Vela R, DíazHerrera MÁ, de Miguel-Montoya I, Martínez-Riera JR (2018). Essential elements of professional nursing environments in Primary Care and their influence on the quality of care. Enferm Clin 28(1): 27-35. DOI: 10.1016/j.enfcli.2017.07.008.

28. Gea-Cabalero V, Juárez-Vela R, Díaz-Herrera MÁ, MármolLópez M-I, Blazquez RA, Martínez-Riera JR (2019). Development of a short questionnaire based on the Practice Environment Scale-Nursing Work Index in primary health care. PeerJ 7: e7369. DOI: 10.7717/peerj.7369.

29. Gikopoulou D, Tsironi M, Lazakidou A, Moisoglou I, Prezerakos P (2014). The Assessment of Nurses' Work Environment: The Case of a Greek General Hospital. Int J Car Sci 7(1): 269-275.

30. Government Decree No. 246/2018 Coll., National Occupational Health and Safety Policy of the Czech Republic [Nařízení vlády č. 246 ze dne 3. ř́ijna 2018, kterým se stanoví podmínky ochrany zdraví při práci, ve znění pozdějších předpisů]. In: Sbírka zákonů Ceské republiky, částka 124, pp. 4250-4266.

31. Hayes B, Bonner A, Douglas C (2015). Haemodialysis work environment contributors to job satisfaction and stress: a sequential mixed methods study. BMC Nurs 14: 58. DOI: 10.1186/s12912-015-0110-x.

32. Hegney D, Eley R, Osseiran-Moisson R, Francis K (2015). Work and personal well-being of nurses in Queensland: Does rurality make a difference? Aust J Rural Health 23(6): 359-365. DOI: 10.1111/ajr.12206.

33. Hinno S, Partanen P, Vehviläinen-Julkunen K (2012). The professional nursing practice environment and nurse-reported job outcomes in two European countries: a survey of nurses in Finland and the Netherlands. Scand J Caring Sci 26(1): 133-143. DOI: 10.1111/j.1471-6712.2011.00920.x.

34. Hinsley KE, Marshall AC, Hurtig MH, Thornton JM, O'Connell CA, Porter CL, et al. (2016). Monitoring the health of the work environment with a daily assessment tool: the REAL Relative Environment Assessment Lens - indicator. Cardiol Young 26(6): 1082-1089. DOI: 10.1017/S1047951115001808.

35. ISO 6385:2016 (2016). Ergonomické zásady navrhování pracovních systémů. Praha: Úřad pro technickou normalizaci, metrologii a státní zkušebnictví, 28 p.

36. Ispir O, Duygulu S (2017). The Control over Nursing Practice Scale: Reliability and Validity of the Turkish Version of the Instrument. Int J Car Sci 10(2): 647-656.

37. Jarošová D, Zeleníková R (2017). Překlad české verze dotazníku PES-NWI. Ostrava: Ostravská univerzita, Lékařská fakulta, Ústav ošetřovatelství a porodní asistence.

38. Klugar M (2015). Systematická review ve zdravotnictví Olomouc: Univerzita Palackého v Olomouci, 121 p.

39. Kolman L, Michálek $\mathrm{P}$, Chýlová $\mathrm{H}$, Rymešová $\mathrm{P}$ (2009). Pojednání o vlivech na koncipování a vývoj teorií motivace pracovní činnosti. Československá psychologie 53(6): 618-627.

40. Kurjenluoma K, Rantanen A, McCormack B, Slater P, Hahtela N, Suominen T (2017). Workplace culture in psychiatric nursing described by nurses. Scand J Caring Sci 31(4): 1048-1058. DOI: $10.1111 /$ scs.12430.

41. Lake ET (2002). Development of the Practice Environment Scale of the Nursing Work Index. Res Nurs Health 25(3): 176-188. DOI: $10.1002 /$ nur.10032.

42. Lake ET (2007). The nursing practice environment: measurement and evidence. Med Care Res Rev 64(Suppl. 2): 104S-122S. DOI: 10.1177/1077558707299253.

43. Lake ET, Friese CR (2006). Variations in nursing practice environments: relation to staffing and hospital characteristics. Nurs Res 55(1): 1-9. DOI: 10.1097/00006199-20060100000001.

44. Lin S-Y, Lin C-H, Yeh MC, Lin S-Y, Hwang Y-J (2011). A psychometric evaluation of the Taiwan version of the 
Individual Workload Perception Scale. J Clin Nurs 20(3-4): 494-503. DOI: 10.1111/j.1365-2702.2010.03495.x.

45. Liu J, Zhou H, Yang X (2017). Evaluation and Improvement of the Nurse Satisfactory Status in a Tertiary Hospital using the Professional Practice Environment Scale. Med Sci Monit 23: 874-880. DOI: 10.12659/msm.902249.

46. Mainz H, Baernholdt M, Ramlau-Hansen C, Brink O (2015). Comparison of nurse practice environments in Denmark and the USA. Int Nurs Rev 62(4): 479-488. DOI: 10.1111/ inr.12208.

47. Mikšová Z, Gurková E, Labudíková M, Chocholková D (2020). Vztah mezi pracovním prostředím sester a nedokončenou ošetřovatelskou péčí - průřezová korelační studie. In: Kudlová $\mathrm{P}$, Pavelková J (Eds). Rodina - zdraví - nemoc: sborník abstrakt z mezinárodní konference. Zlín: Univerzita Tomáše Bati ve Zlíně, Fakulta humanitních studií, pp. 67-68.

48. Moher D, Liberati A, Tetzlaff J, Altman DG (2009). Preferred Reporting Items for Systematic Reviews and Meta-Analyses: The PRISMA Statement. PLoS Med 6(7): e1000097. DOI: 10.1371/ journal.pmed1000097.

49. Monroe M, Morse E, Price JM (2020). The Relationship between Critical Care Work Environment and Professional Quality of Life. Am J Crit Care 29(2): 145-149. DOI: 10.4037/ ajcc2020406.

50. Nantsupawat A, Kunaviktikul W, Nantsupawat R, Wichaikhum O-A, Thienthong H, Poghosyan L (2017). Effects of nurse work environment on job dissatisfaction, burnout, intention to leave. Int Nurs Rev 64(1): 91-98. DOI: 10.1111/ inr.12342.

51. Norman RM, Sjetne IS (2017). Measuring nurses' perception of work environment: a scoping review of questionnaires. BMC Nurs 16: 66. DOI: 10.1186/s12912-017-0256-9.

52. Novotná H (2018). Organizační a psychosociální faktory práce sester na vybraných pracovištích FN Motol. Praha: Univerzita Karlova, 2. lékařská fakulta, Ústav ošetřovatelství, 92 p. Vedoucí bakalářské práce PhDr. RNDr. Daniel Jirkovský, Ph.D., MBA.

53. NQF - National Quality Forum (2004). National voluntary consensus standards for nursing-sensitive care: An initial performance measurement set - A consensus report. [online] [cit. 2021-05-05]. Available from: https://www.qualityforum. org/Publications/2004/10/National_Voluntary_Consensus_ Standards_for_Nursing-Sensitive_Care_An_Initial_ Performance_Measure_Set.aspx

54. Olecká I, Ivanová K (2010). Metodologie vědecko-výzkumné činnosti. Olomouc: Moravská vysoká škola Olomouc, a. s.

55. Oshodi TO, Crockett R, Bruneau B, West E (2017). The nursing work environment and quality of care: A cross-sectional study using the Essentials of Magnetism II Scale in England. J Clin Nurs 26(17-18): 2721-2734. DOI: 10.1111/jocn.13783.

56. Pai HC, Lee $S$, Chang T (2011). A confirmatory factor analysis of the Clinical Nursing Practice Environment Scale with hospital registered nurses in Taiwan. J Clin Nurs 20(15-16): 2344-2354. DOI: $10.1111 / \mathrm{j} .1365-2702.2010 .03544 . x$.

57. Panunto MR, Guirardello EB (2013). Professional nursing practice: environment and emotional exhaustion among intensive care nurses. Rev Lat Am Enfermagem 21(3): 765-772. DOI: 10.1590/S0104-11692013000300016.

58. Papastavrou E, Efstathiou G, Acaroglu R, DA Luz MD, Berg A, Idvall E, et al. (2012). A seven country comparison of nurses' perceptions of their professional practice environment. J Nurs Manag 20(2): 236-248. DOI: 10.1111/j.13652834.2011.01289.x.

59. Park SH, Hanchett M, Ma C (2018). Practice Environment Characteristics Associated with Missed Nursing Care. J Nurs Scholarsh 50(6): 722-730. DOI: 10.1111/jnu.12434.

60. Perry SJ, Richter JP, Beauvais B (2018). The Effects of Nursing Satisfaction and Turnover Cognitions on Patient Attitudes and Outcomes: A Three-Level Multisource Study. Health Serv Res 53(6): 4943-4969. DOI: 10.1111/1475-6773.12997.

61. Pires BSM, Oliviera LZF, Siqueira CL, Feldman LB, Oliveira RA, Gasparino RC (2018). Nurse work environment: comparison between private and public hospitals. Einstein (São Paulo) 16(4): 1-6. DOI: 10.31744/einstein_journal/2018AO4322.
62. Polanská $\mathrm{A}$, Jarošová $\mathrm{D}$, Janíková E, Mynaříková E, Plevová I, Zeleníková R (2020). Opomíjená a chybějící ošetřovatelská péče v nemocnici - pilotní studie. Prakt Lék 100(4): 192-195.

63. Pryse Y, McDaniel A, Schafer J (2014). Psychometric Analysis of Two New Scales: The Evidence-Based Practice Nursing Leadership and Work Environment Scales. Worldviews Evid Based Nurs 11(4): 240-247. DOI: 10.1111/wvn.12045.

64. Purdy N, Lanschinger HKS, Finegan J, Kerr M, Olivera F (2010). Effects of work environments on nurse and patient outcomes. J Nurs Manag 18(8): 901-913. DOI: 10.1111/j.13652834.2010.01172.x.

65. Rabie T (2019). Construct validity and internal consistency of Hall's Professionalism Scale: tested on South African nurses. BMC Res Notes 12(1): 486. DOI: 10.1186/s13104-019-4515-6.

66. Rabie T, Coetzee SK, Klopper HC (2016). The nature of community health care centre practice environments in a province in South Africa. Afr J Nurs Midwifery 18(2): 27-41. DOI: $10.25159 / 2520-5293 / 216$.

67. Raju D, Su X, Patrician PA (2014). Using Item Response Theory Models to Evaluate the Practice Environment Scale. J Nurs Meas 22(2): 323-341. DOI: 10.1891/1061-3749.22.2.323.

68. Reid C, Courtney M, Anderson D, Hurst C (2015). Testing the psychometric properties of the Brisbane Practice environment Measure using Exploratory Factor Analysis in an Australian registered Nurse Population. Int J Nurs Pract 21(1): 94-101. DOI: $10.1111 /$ ijn.12225.

69. Ross AM, Ilic K, Kiyoshi-Teo H, Lee CS (2018). Psychometric analysis of the leadership environment scale (LENS): Outcome from the Oregon research initiative on the organisation of nursing (ORION). J Nurs Manag 26(4): 467-476. DOI: 10.1111/ jonm.12572.

70. Schadewaldt V, McElduff B, D’Este C, McInnes E, Dale S, Gunaratne A, et al. (2019). Validating the Alberta Context Tool in a multi-site Australian Emergency Department nurse population. PLoS One 14(4): e0215153. DOI: 10.1371/journal. pone.0215153.

71. Sheingold BH, Sheingold SH (2013). Using a social capital framework to enhance measurement of the nursing work environment. J Nurs Manag 21(5): 790-801. DOI: 10.1111/ jonm.12127.

72. Siedlecki SL, Hixon ED (2011). Development and Psychometric Exploration of the Professional Practice Environment Assessment Scale. J Nurs Scholarsh 43(4): 421-425. DOI: 10.1111/j.1547-5069.2011.01414.x.

73. Silva RPL, Menegueti MG, Siqueira LDC, de Araújo TR, Auxiliadora-Martins M, Andrade LMS, Laus AM (2020). Omission of nursing care, professional practice environment and workload in intensive care units. J Nurs Manag 28(8): 1986-1996. DOI: 10.1111/jonm.13005.

74. Sirin M, Sokmen SM (2015). Quality of Nursing Work Life Scale: The Psychometric Evaluation of the Turkish version. Int J Car Sci 8(3): 543-554.

75. Slater P, McCormack B (2007). An Exploration of the Factor Structure of the Nursing Work Index. Worldviews Evid Based Nurs 4(1): 30-39. DOI: 10.1111/j.1741-6787.2007.00076.x.

76. Slater P, O'Halloran P, Connolly D, McCormack D (2010). Testing of the Factor Structure of the Nursing Work IndexRevised. Worldviews Evid Based Nurs 7(3): 123-134. DOI: 10.1111/j.1741-6787.2009.00158.x.

77. Smith JG, Morin KH, Lake ET (2018). Association of the nurse work environment with nurse incivility in hospitals. J Nurs Manag 26(2): 219-226. DOI: 10.1111/jonm.12537.

78. Swiger PA, Raju D, Breckenridge-Sproat S, Patrician PA (2017). Adaptation of the Practice Environment Scale for military nurses: a psychometric analysis. J Adv Nurs 73(9): 2219-2236. DOI: 10.1111/jan.13276.

79. Tang WM, Idris AR (2016). Nursing practice environment as perceived by the Malaysian private hospital nurses. IeJSME 10(2): 11-20.

80. Tucker SJ, Harris MR, Pipe TB, Stevens SR (2010). Nurses' ratings of their health and professional work environments. AAOHN J 58(6): 253-267. DOI: 10.3928/08910162-2010052603. 
81. Ulusoy H, Polatkan R (2016). Assessment of the nurses' work environment using the nursing work index scale. Cumhur Medical J 38(4): 246-257. DOI: 10.7197/cmj. v38i3.5000196868.

82. Van Bogaert P, Clarke S, Willems R, Mondelaers M (2013a). Nurse practice environment, workload, burnout, job outcomes, and quality of care in psychiatric hospitals: A structural equation model approach. J Adva Nurs 69(7): 1515-1524. DOI: 10.1111/jan.12010.

83. Van Bogaert P, Kowalski C, Weeks SM, Heusden DV, Clarke SP (2013b). The relationship between nurse practice environment, nurse work characteristics, burnout and job outcome and quality of nursing care: A cross-sectional survey. Int J Nurs Stud 50(12): 1667 - 1677. DOI: 10.1016/j.ijnurstu.2013.05.010.

84. Van Bogaert P, Timmermans O, Weeks SM, van Heusden D, Wouters K, Franck E (2014). Nursing unit teams matter: Impact of unit-level nurse practice environment, nurse work characteristics, and burnout on nurse reported outcomes, and quality of care, and patient adverse events. A cross-sectional survey. Int J Nurs Stud 51(8): 1123-1134. DOI: 10.1016/j. ijnurstu.2013.12.009.

85. Van Bogaert P, Wouters K, Willems R, Mondelaers M, Clarke S (2013c). Work engagement supports nurse workforce stability and quality of care: nursing team-level analysis in psychiatric hospital. J Psychiatr Ment Health Nurs 20(8): 679 - 686. DOI: 10.1111/jpm.12004.

86. Verulava T, Jorbenadze R, Dangadze B, Karimi L (2018). Nurses' Work Environment Characteristics and Job Satisfaction: Evidence from Georgia. GMJ 29(1): 12-16. DOI: 10.12996/ gmj.2018.04.
87. Vévoda J, et al. (2013). Motivace sester a pracovní spokojenost ve zdravotnictví. Praha: Grada, 160 p.

88. Walket K, Middleton S, Rolley J, Duff J (2010). Nurses report a healthy culture: Results of the Practice Environment Scale (Australia) in an Australian hospital seeking Magnet recognition. Int J Nurs Pract 16(6): 616-623. DOI: 10.1111/j.1440-172X.2010.01890.x.

89. Wang Y, Dong W, Mauk K, Li P, Wan J, Yang G, et al. (2015). Nurses' Practice Environment and Their Job Satisfaction: A Study on Nurses Caring for Older Adults in Shanghai. PLoS One 10(9): e0138035. DOI: 10.1371/journal.pone.0138035.

90. Warshawsky NE, Havens DS (2011). Global use of the practice environment scale of the nursing work index. Nurs Res 60(1): 17-31. DOI: 10.1097/NNR.0b013e3181ffa79c.

91. Zeleníková R, Jarošová D, Plevová I, Janíková E (2020). Nurses' perceptions of professional practice environment and its relation to missed nursing care and nurse satisfaction. Int J Environ Res Public Health 17(11): 3805. DOI: 10.3390/ ijerph17113805.

92. Žežulková $Z$ (2018). Psychosociální a organizační faktory v práci sester ve vybraných nestátních zdravotnických zařízeních lůžkového typu. Praha: Univerzita Karlova, 2. lékařská fakulta, Ústav ošetřovatelství, $97 \mathrm{p}$.

93. Zhao P, Chen FJ, Jia XH, Lv H, Cheng PP, Zhang LP (2013). The validation and application of the Chinese version of perceived nursing work environment scale. J Clin Nurs 22(13-14): 1827-1832. DOI: 10.1111/jocn.12229. 


\section{Supplementary material}

\section{Suppl. Table 1. Descriptions of work environment assessment instruments}

\begin{tabular}{|c|c|c|c|c|c|}
\hline $\begin{array}{l}\text { Instrument name, author, } \\
\text { abbreviation / number of } \\
\text { studies identified }\end{array}$ & Study author, year & $\begin{array}{l}\text { Number } \\
\text { of items }\end{array}$ & Domains/subscales & $\begin{array}{l}\text { Response } \\
\text { format }\end{array}$ & Reliability ( $\alpha$ ) \\
\hline $\begin{array}{l}\text { Alberta Context Tool (Estabrooks } \\
\text { et al., 2009) } \\
\text { ACT / } 1\end{array}$ & $\begin{array}{l}\text { Schadewaldt et al. } \\
\text { (2019) }\end{array}$ & 56 & $\begin{array}{l}\text { Leadership; Culture; Feedback processes; } \\
\text { Connections; Formal interactions; Informal } \\
\text { interactions; Structural and electronic resources; } \\
\text { Staffing; Time; Space }\end{array}$ & LS 5 & $0.45-0.90(S)$ \\
\hline \multirow{3}{*}{$\begin{array}{l}\text { Brisbane Practice Environment } \\
\text { Measure (Webster et al., 2009) } \\
\text { B-PEM / } 3\end{array}$} & Hayes et al. (2015) & \multirow{2}{*}{26} & \multirow{2}{*}{$\begin{array}{l}\text { PD; Getting things done; Flexibility in } \\
\text { management support; Feeling valued }\end{array}$} & \multirow{2}{*}{ Not stated } & $\begin{array}{c}0.91(\mathrm{TS}) \\
0.80-0.86(\mathrm{~S})\end{array}$ \\
\hline & Flint et al. (2010) & & & & $\begin{array}{c}0.94(\mathrm{TS}) \\
0.81-0.87(\mathrm{~S})\end{array}$ \\
\hline & Reid et al. (2015) & 28 & $\begin{array}{l}\text { PD; Management Support; Rostering; Out of } \\
\text { depth; Workloads }\end{array}$ & LS 5 & $\begin{array}{c}0.94(\mathrm{TS}) \\
0.66-0.89(\mathrm{~S})\end{array}$ \\
\hline $\begin{array}{l}\text { Control Over Nursing Practice } \\
\text { Scale (Gerber et al., 1990) } \\
\text { CONP-S / } 1\end{array}$ & $\begin{array}{l}\text { Ispir and Duygulu } \\
\text { (2017) }\end{array}$ & 23 & Not specified (1) & LS 7 & $\begin{array}{l}0.94 \\
0.76\end{array}$ \\
\hline $\begin{array}{l}\text { Essentials of Magnetism II scale } \\
\text { (Kramer and Hafner, 1989) } \\
\text { EOMII / } 1\end{array}$ & Oshodi et al. (2017) & 58 & $\begin{array}{l}\text { Ward manager support; Working as a team; } \\
\text { Concern for patients; Organisational A; } \\
\text { Constraints on nursing practice }\end{array}$ & \multirow[b]{2}{*}{ LS 4} & $0.76-0.94$ \\
\hline $\begin{array}{l}\text { Evidence-Based Work } \\
\text { Environment Scale (Pryse et al., } \\
\text { 2014) } \\
-/ 1\end{array}$ & Pryse et al. (2014) & 8 & $\begin{array}{l}\text { EBP WE Scale } \\
\text { EBP Nursing Leadership Scale }\end{array}$ & & $\begin{array}{l}0.86 \\
0.96\end{array}$ \\
\hline $\begin{array}{l}\text { Hall's Professionalism Scale } \\
\text { (Hall, 1968; Snizek, 1972) } \\
\text { HPS / } 1\end{array}$ & Rabie (2019) & 25 & $\begin{array}{l}\text { A; Using a professional organisation as major } \\
\text { referent; Belief in public services; Belief in self- } \\
\text { regulation; Sense of calling to the field }\end{array}$ & LS 5 & $\begin{array}{l}0.86 \\
0.79\end{array}$ \\
\hline $\begin{array}{l}\text { Healthy Work Environment } \\
\text { Assessment Tool (American } \\
\text { association of Critical Care } \\
\text { Nurses) } \\
\text { HWEAT / } 1\end{array}$ & Monroe et al. (2020) & 18 & $\begin{array}{l}\text { Skilled communication, true collaboration, } \\
\text { effective decision-making, appropriate staffing, } \\
\text { meaningful recognition, authentic leadership }\end{array}$ & LS 3 & 0.8 or higher \\
\hline $\begin{array}{l}\text { Chinese version of Perceived } \\
\text { Nursing Work Environment } \\
\text { (Choi et al., 2004) } \\
\text { C-PNWE / } 1\end{array}$ & Zhao et al. (2013) & 41 & $\begin{array}{l}\text { SRA; Professional practice; Nursing } \\
\text { management; Nursing Process; Nurse/Physician } \\
\text { collaboration; Nursing competence and work } \\
\text { system }\end{array}$ & \multirow[t]{2}{*}{ LS 4} & $\begin{array}{c}0.96(\mathrm{TS}) \\
0.79-0.93(\mathrm{~S})\end{array}$ \\
\hline $\begin{array}{l}\text { Leadership Environment Scale } \\
\text { (Ross et al., 2018) } \\
\text { LENS / } 1\end{array}$ & Ross et al. (2018) & 16 & $\begin{array}{l}\text { Self-organisation; Agents; Shared power and } \\
\text { decision making; Emergence; Transformative } \\
\text { Exchanges; Different perspectives; Co-evolution }\end{array}$ & & $\begin{array}{c}0.91(\mathrm{TS}) \\
0.86 \text { a } 0.85(\mathrm{~S})\end{array}$ \\
\hline $\begin{array}{l}\text { Modified 6-D Scale of Nursing } \\
\text { Performance Marshalleck, 1997); } \\
\text { (Schwirian, 1978; } \\
-/ 1\end{array}$ & $\begin{array}{l}\text { Bratt and Felzer } \\
\text { (2011) }\end{array}$ & 61 & $\begin{array}{l}\text { PD; Critical care; Interpersonal relations/ } \\
\text { communications; Leadership; Managing/ } \\
\text { outcomes; Planning/evaluation; Teaching/ } \\
\text { collaboration }\end{array}$ & LS 5 & $\begin{array}{c}0.95(\mathrm{TS}) \\
0.71-0.90(\mathrm{~S})\end{array}$ \\
\hline $\begin{array}{l}\text { Person Centered Nursing Index } \\
\text { (Slater and McCormack, 2007) } \\
\text { PCNI / } 1\end{array}$ & $\begin{array}{l}\text { Kurjenluoma et al. } \\
\text { (2017) }\end{array}$ & 78 & Stress, job satisfaction, practice environment & LS 7 & $0.58-0.93$ \\
\hline
\end{tabular}




\section{Suppl. Table 1. (continued)}

\begin{tabular}{|c|c|c|c|c|c|}
\hline $\begin{array}{l}\text { Instrument name, author, } \\
\text { abbreviation / number of } \\
\text { studies identified }\end{array}$ & Study author, year & $\begin{array}{l}\text { Number } \\
\text { of items }\end{array}$ & Domains/subscales & $\begin{array}{l}\text { Response } \\
\text { format }\end{array}$ & Reliability ( $\alpha$ ) \\
\hline \multirow{9}{*}{$\begin{array}{l}\text { Nursing Work Index (Aiken and } \\
\text { Patrician, 2000; } \\
\text { Brazilian version Gasparino and } \\
\text { Guirardello, 2011; } \\
\text { Belgian version Van Bogaert et } \\
\text { al., 2009) } \\
\text { NWI / } 9\end{array}$} & Pires et al. (2018) & \multirow{4}{*}{15} & A; RDN; Control over the WE & \multirow{15}{*}{ LS 4} & Not stated \\
\hline & Costa et al. (2018) & & \multirow[b]{2}{*}{ A; RDN; OS; Control over the environment } & & Not stated \\
\hline & $\begin{array}{l}\text { Panunto and } \\
\text { Guirardello (2013) }\end{array}$ & & & & $0.73-0.82(S)$ \\
\hline & $\begin{array}{l}\text { Balsanelli and } \\
\text { Cunha (2013) }\end{array}$ & & A; RDN; OS; CP & & $\begin{array}{l}0.811(\mathrm{TS}) \\
0.645-0.748 \\
\quad(\mathrm{~S})\end{array}$ \\
\hline & Slater et al. (2010) & 33 & \multirow[b]{2}{*}{ A; RDN; OS; CP } & & $0.80-0.87(S)$ \\
\hline & $\begin{array}{l}\text { Cortelyou-Ward et } \\
\text { al. (2010) }\end{array}$ & 57 & & & $\begin{array}{c}0.947(\mathrm{TS}) \\
0.78-0.86(\mathrm{~S})\end{array}$ \\
\hline & Hinno et al. (2012) & 35 & $\begin{array}{l}\text { Adequacy of resources; Supportiveness of } \\
\text { management; Assurance of care quality via } \\
\text { collaborative relationships }\end{array}$ & & $0.77-0.86$ \\
\hline & $\begin{array}{l}\text { Van Bogaert et al. } \\
\text { (2013) }\end{array}$ & \multirow{2}{*}{31} & \multirow{2}{*}{$\begin{array}{l}\text { RDN; unit-level nurse management; hospital } \\
\text { management-OS }\end{array}$} & & Not stated \\
\hline & $\begin{array}{l}\text { Van Bogaert et al. } \\
\text { (2014) }\end{array}$ & & & & Not stated \\
\hline \multirow{6}{*}{$\begin{array}{l}\text { Practice Environment Scale } \\
\text { (Lake, 2002) } \\
\text { PES / } 5 \\
\text { Nursing Practice Environment } \\
\text { Scale (Lake, 2002; } \\
\text { Chinese version Wang, 2011) } \\
\text { NPES / } 1\end{array}$} & $\begin{array}{l}\text { Ganz and Toren } \\
\text { (2014) }\end{array}$ & 31 & \multirow{6}{*}{ NPHA; NFQC; NMALSN; SRA; RDN } & & \multirow[t]{2}{*}{ Not stated } \\
\hline & Verulava et al. (2018 & 30 & & & \\
\hline & Cheng et al. (2020) & \multirow[t]{2}{*}{31} & & & $\begin{array}{c}0.91(\mathrm{TS}) \\
0.67-0.79(\mathrm{~S})\end{array}$ \\
\hline & Raju et al. (2014) & & & & Not stated \\
\hline & $\begin{array}{l}\text { Gasparino and } \\
\text { Guirardello (2017) }\end{array}$ & \multirow[t]{2}{*}{24} & & & $0.80-0.86$ \\
\hline & Silva et al. (2020) & & & & Not stated \\
\hline $\begin{array}{l}\text { Clinical Nursing Practice } \\
\text { Environment Scale (Pai et al., } \\
\text { 2011) } \\
\text { CN-PES / } 1\end{array}$ & Pai et al. (2011) & 29 & $\begin{array}{l}\text { Availability of safety equipment and devices; } \\
\text { Pay and benefit; Mutual respect and support } \\
\text { among co-workers; Support of advance in-service } \\
\text { training; Workforce security and safety }\end{array}$ & LS 5 & $\begin{array}{c}0.94(\mathrm{TS}) \\
0.8-0.93(\mathrm{~S})\end{array}$ \\
\hline
\end{tabular}




\section{Suppl. Table 1. (continued)}

\begin{tabular}{|c|c|c|c|c|c|}
\hline $\begin{array}{l}\text { Instrument name, author, } \\
\text { abbreviation / number of } \\
\text { studies identified }\end{array}$ & Study author, year & $\begin{array}{l}\text { Number } \\
\text { of items }\end{array}$ & Domains/subscales & $\begin{array}{l}\text { Response } \\
\text { format }\end{array}$ & Reliability ( $\alpha$ ) \\
\hline \multirow{20}{*}{$\begin{array}{l}\text { Practice Environment Scale- } \\
\text { Nursing Work Index (Lake, 2002; } \\
\text { Korean version Cho et al., 2011; } \\
\text { Turkish version Türkmen et } \\
\text { al., 2011; Spanish version De } \\
\text { Pedro Gómez, 2012; Greek } \\
\text { version Prezerakos et al., 2013; } \\
\text { Australian version Parker et al., } \\
\text { 2010; Thai version Nantsupawat } \\
\text { et al., 2011) } \\
\text { PES-NWI / } 20\end{array}$} & $\begin{array}{l}\text { Efstathiou et al. } \\
\text { (2018) }\end{array}$ & 32 & $\begin{array}{l}\text { SRA; RDN; Nursing Policy; Nursing management } \\
\text { and development; Nursing competency }\end{array}$ & \multirow{4}{*}{ LS 4} & $\begin{array}{c}0.93(\mathrm{TS}) \\
0.71-0.94(S)\end{array}$ \\
\hline & Cho and Han (2018) & - & NMALSN; SRA; RDN & & $0.72-0.81(S)$ \\
\hline & $\begin{array}{l}\text { Ulusoy and Polatkan } \\
\text { (2016) }\end{array}$ & \multirow[t]{2}{*}{31} & $\begin{array}{l}\text { Nurses' participation and representation rate in } \\
\text { the management; Nursing foundations needed } \\
\text { for quality care; Nurse Managers' attitudes and } \\
\text { leadership traits; Adequacy of staff (work force) } \\
\text { and other resources; Communication between } \\
\text { physicians and nurses }\end{array}$ & & Not stated \\
\hline & Asiret et al. (2017) & & SRA; NFQC; NPHA; RDN; NMALSN & & 0.82 \\
\hline & $\begin{array}{l}\text { Gea-Cabalero et at. } \\
(2018)\end{array}$ & 10 & $\begin{array}{l}\text { Participation in management and leadership; } \\
\text { Focus on nursing care and interdisciplinary } \\
\text { relationships; Adequate resources }\end{array}$ & Not stated & 0.82 \\
\hline & Wang et al. (2015) & \multirow{4}{*}{31} & SRA; NFQC; NPHA; RDN; NMALSN & \multirow{4}{*}{ LS 4} & 0.82 \\
\hline & Flynn et al. (2012) & & \multirow[b]{2}{*}{$\begin{array}{l}\text { SRA; NFQC; NPHA; RDN; Supportive and } \\
\text { Competent Nurse Manager }\end{array}$} & & 0.95 \\
\hline & $\begin{array}{l}\text { Tang and Idris } \\
\text { (2016) }\end{array}$ & & & & $\begin{array}{c}0.90(\mathrm{TS}) \\
0.66-0.81(\mathrm{~S})\end{array}$ \\
\hline & Al Sabei et al. (2020) & & SRA; NFQC; NPHA; RDN; NMALSN & & 0.98 (TS) \\
\hline & Friese & 25 & $\begin{array}{l}\text { SRA; NFQC; NPHA; RDN; NMALSN; Medical } \\
\text { assistant support }\end{array}$ & LS 5 & $0.80-0.90(S)$ \\
\hline & $\begin{array}{l}\text { Gikopoulou et al. } \\
\text { (2014) }\end{array}$ & 31 & SRA; NFQC; NPHA; RDN; NMALSN & \multirow{4}{*}{ LS 4} & $\begin{array}{c}0.89(\mathrm{TS}) \\
0.70-0.80(\mathrm{~S})\end{array}$ \\
\hline & Perry et al. (20185) & 25 & $\begin{array}{l}\text { Supportive leadership; Staffing adequacy; Nurse- } \\
\text { physician teamwork; Nursing care practice; } \\
\text { Advancement opportunities }\end{array}$ & & $0.77-0.91(S)$ \\
\hline & Rabie et al. (2016) & 32 & \multirow{6}{*}{ SRA; NFQC; NPHA; RDN; NMALSN } & & $\begin{array}{c}0.86(\mathrm{TS}) \\
0.68-0.86(S)\end{array}$ \\
\hline & Elmi et al. (2017) & 30 & & & $\begin{array}{c}0.935(\mathrm{TS}) \\
0.70-0.92(\mathrm{~S})\end{array}$ \\
\hline & Hegney et al. (2015) & - & & Not stated & Not stated \\
\hline & Park et al. (2018 & \multirow{5}{*}{31} & & & Not stated \\
\hline & Swiger et al. (2017) & & & & $\begin{array}{c}0.96(\mathrm{TS}) \\
0.81-0.90(\mathrm{~S})\end{array}$ \\
\hline & Mainz et al. (2015) & & & & $\begin{array}{c}0.88(\mathrm{TS}) \\
0.71-0.82(\mathrm{~S})\end{array}$ \\
\hline & $\begin{array}{l}\text { Gea-Cabalero et at. } \\
(2019)\end{array}$ & & $\begin{array}{l}\text { NPHA; RDN; Nursing merits for care quality; } \\
\text { Leadership of coordination; Human resources }\end{array}$ & & Not stated \\
\hline & $\begin{array}{l}\text { Nantsupawat et al. } \\
\text { (2017) }\end{array}$ & & SRA; NFQC; NPHA; RDN; NMALSN & & Not stated \\
\hline $\begin{array}{l}\text { Professional Practice } \\
\text { Environment Assessment Scale } \\
\text { (Siedlecki and Hixon, 2011) } \\
\text { PPEAS / } 1\end{array}$ & $\begin{array}{l}\text { Siedlecki and Hixon } \\
\text { (2011) }\end{array}$ & 13 & $\begin{array}{l}\text { Positive physician characteristics; Positive nurse } \\
\text { characteristics; Collaborative decision making; } \\
\text { Positive beliefs in the value of the nurse- } \\
\text { physician relationship }\end{array}$ & LS 10 & $\begin{array}{c}0.86 \text { (TS) } \\
0.73-0.89(\mathrm{~S}\end{array}$ \\
\hline $\begin{array}{l}\text { Professional Practice } \\
\text { Environment Scale (Chiang and } \\
\text { Lin, 2008) } \\
\text { CPPE-38 / } 1\end{array}$ & Liu et al. (2017) & 38 & $\begin{array}{l}\text { IR and A; CP; Internal work motivation; } \\
\text { Interpersonal interaction; Supportive leadership } \\
\text { and handling conflict }\end{array}$ & Not stated & Not stated \\
\hline $\begin{array}{l}\text { Quality of Nursing Work Life } \\
\text { Survey (Brooks, 2001) } \\
\text { QNWL / } 1\end{array}$ & $\begin{array}{l}\text { Sirin and Sokmen } \\
(2015)\end{array}$ & 35 & $\begin{array}{l}\text { WE; Relations with managers; Work conditions; } \\
\text { Job perception; Support services }\end{array}$ & LS 6 & $\begin{array}{c}0.89(\mathrm{TS}) \\
0.62-0,81(\mathrm{~S})\end{array}$ \\
\hline $\begin{array}{l}\text { Revised Individual Workload } \\
\text { Perception Scale (Cox et al., } \\
\text { 2006) } \\
\text { R-IWPS / } 1\end{array}$ & Lin et al. (2011) & 24 & $\begin{array}{l}\text { Manager support; Peer support; Intent to stay; } \\
\text { Workload; Unit support }\end{array}$ & LS 5 & $\begin{array}{c}0.88(\mathrm{TS}) \\
0.61-0.85(\mathrm{~S})\end{array}$ \\
\hline
\end{tabular}




\section{Suppl. Table 1. (continued)}

Instrument name, author, abbreviation / number of studies identified

Revised Professional Practice Environment (Erickson et al., 2009)

RPPE / 2

Chinese version Professional Practice Environment (Erickson et al., 2004)

CPPE / 1

Relative Environment Assessment Lens (Boston

Children's Hospital, 2015)

REAL / 1

Social Capital-Integrated

Questionnaire (Jones and

Woolcock, 2007)

SC-IQ / 1

\begin{tabular}{|c|c|c|c|c|}
\hline Study author, year & $\begin{array}{l}\text { Number } \\
\text { of items }\end{array}$ & Domains/subscales & $\begin{array}{l}\text { Response } \\
\text { format }\end{array}$ & Reliability ( $\alpha$ ) \\
\hline $\begin{array}{l}\text { Papastavrou et al. } \\
\text { (2012) }\end{array}$ & \multirow{2}{*}{39} & \multirow{2}{*}{$\begin{array}{l}\text { Leadership and A; CP; Communication about } \\
\text { Patients; Teamwork; Handling Disagreements; } \\
\text { Staff Relationship with Physicians; Internal Work } \\
\text { Motivation, Cultural Sensitivity }\end{array}$} & \multirow{2}{*}{ LS 4} & $\begin{array}{l}0.84-0.93 \\
\text { (TS) }\end{array}$ \\
\hline $\begin{array}{l}\text { Zeleníková et al. } \\
\text { (2020) }\end{array}$ & & & & $\begin{array}{c}0.89(\mathrm{TS}) \\
0.59-0.80(\mathrm{~S})\end{array}$ \\
\hline Cao et al. (2015) & 38 & $\begin{array}{l}\text { Work motivation; CP; Interpersonal interaction; } \\
\text { Supportive leadership and handling conflict; IR } \\
\text { and A }\end{array}$ & LS 4 & Not stated \\
\hline Hinsley et al. (2016) & 9 & Unnamed 8 & $\begin{array}{l}\text { Faces } \\
\text { scale } 6\end{array}$ & Not stated \\
\hline $\begin{array}{l}\text { Sheingold and } \\
\text { Sheingold (2013) }\end{array}$ & 28 & $\begin{array}{l}\text { External trust; Solidarity and Empowerment; } \\
\text { Participation and Affiliation; Internal Trust; } \\
\text { Solidarity and Harmony; Social Cohesion with } \\
\text { co-workers, Conflict }\end{array}$ & LS 5 & $\begin{array}{c}0.92 \text { (TS) } \\
0.61-0.90(\mathrm{~S})\end{array}$ \\
\hline
\end{tabular}

EBP - evidence-based practice; WE - work environment; TS - total score; S - subscales, A - autonomy, RDN - relationship between doctors and nurses/nursing team; IR - internal relationship; CP - control over the practice, OS - organizational support, SRA - staffing and resources adequacy, NPHA - nurse participating in hospital affairs; NFQC - nursing foundations for quality of care; NMALSN - nurse manager ability, leadership and support of nurses; PD - professional development 